\title{
Synthesis of Azidothymidine-Bound Curdlan Sulfate with Anti-Human Immunodeficiency Virus Activity in Vitro
}

\author{
Ying GaO, Kaname Katsuraya, Yutaro Kaneko, ${ }^{*}$ Toru Mimura,* \\ Hideki NAKASHIMA, ${ }^{* *}$ and Toshiyuki $\mathrm{URYU}^{\dagger}$ \\ Institute of Industrial Science, The University of Tokyo, Roppongi, Minato-ku, Tokyo, 106, Japan \\ * Ajinomoto Co., Kyobashi, Chuo-ku, Tokyo 104, Japan \\ **Dental School, Kagoshima University, Sakuragaoka, Kagoshima 890, Japan
}

(Received June 16, 1997)

\begin{abstract}
Azidothymidine (AZT) was introduced into curdlan by biodegradable ester bond to give AZT-bound curdlan (AZT-curdlan) in order to aim at releasing AZT from the polymer backbone by an enzymatic hydrolysis in living organs. Structure of the AZT-curdlan was analyzed by ${ }^{13} \mathrm{C}$ NMR and ${ }^{1} \mathrm{H}^{-13} \mathrm{C}$ COSY-FG 2D-NMR spectroscopy, indicating that AZT was bound to C6 hydroxyl group of curdlan as designed. Subsequently, the AZT-curdlan was sulfated with sulfur trioxide-pyridine complex to give sulfated AZT-curdlans (AZT-curdlan sulfates). AZT-curdlan sulfates, in vitro, exhibited anti-HIV activities in the $\mathrm{EC}_{50}$ range of 0.20 to $0.60 \mu \mathrm{g} \mathrm{ml}^{-1}$, corresponding to that $\left(\mathrm{EC}_{50}=0.50 \mu \mathrm{g} \mathrm{ml}^{-1}\right)$ of highly active curdlan sulfate. They possessed low cytotoxicities of $\mathrm{CC}_{50}$ more than $1000 \mu \mathrm{g} \mathrm{ml}^{-1}$ in vitro, indicating that AZT was not released in vitro. However, an increase in the anti-HIV activity and the cytotoxicity was observed when the AZT-curdlan sulfate solution in $90 \%$ buffer at $\mathrm{pH} 7.4$ and $10 \%$ dimethyl sulfoxide mixture was kept in a refrigerator for a few weeks. The phenomenon indicates that an anti-HIV active AZT was released slowly from the curdlan sulfate carrier. Furthermore, the AZT-curdlan sulfates exhibited low to moderate anticoagulant activities in vitro.

KEY WORDS Azidothymidine / Human Immunodeficiency Virus / AIDS / Curdlan Sulfate / Drug Delivery System / Polysaccharide /
\end{abstract}

Although human immunodeficiency virus (HIV) causing AIDS has been believed to be latent virus, it was reported recently that HIV infection is active and progressive in the lymphatic system even in an early period of infection. ${ }^{1,2}$ In fact, the lymphatic system serves as a major reservoir for HIV replication. This discovery suggested that targeting of AIDS drug to lymphatic tissue and sustaining a high therapeutic drug concentration in lymphatic tissue may improve therapeutic benefits, especially in the latent period. However, it has been reported that azidothymidine (AZT) administration during an early clinical latent stage did not provide benefits to HIV-infected patients, ${ }^{3}$ since AZT fails to be targeted and sustained in lymphatic tissue, ${ }^{4,5}$ and has serious side effects and drug resistance. ${ }^{6}$ Therefore, preparation of an AZT prodrug which may deliver AZT to lymphatic tissue and maintain effective AZT concentration in lymphatic tissue is of importance.

Investigations on sulfated oligo- and polysaccharides with potent anti-HIV activities have extensive attracted attention. ${ }^{7-19}$ Of these, curdlan sulfate exhibits a strong anti-HIV activity of $\mathrm{EC}_{50}=0.50 \mu \mathrm{g} \mathrm{ml}^{-1}$ to completely inhibit HIV infection at a concentration as low as $3.3 \mu \mathrm{g} \mathrm{ml}^{-1}$ in vitro, and possesses low anticoagulant activity as well as low cytotoxicity. The phase I/II test of curdlan sulfate has been performed in the United States since $1992 .{ }^{20}$ The results of the clinical trial have demonstrated that administration of the curdlan sulfate increased the number of CD4 lymphocytes in AIDS patients' blood. In addition, it was also found that the curdlan sulfate is concentrated in organs such as liver, kidney, lymph node, and bone marrow. ${ }^{21}$ Therefore, curdlan sulfate may also be expected to act as a delivery carrier of AIDS drug into lymphoid tissue, if an effective

\footnotetext{
† To whom correspondence should be addressed.
}

AIDS drug is bound to the curdlan sulfate.

In the present paper, we reported firstly the preparation of a drug delivery system (DDS) of AZT-bound curdlan sulfate which may be expected to be delivered to lymphatic tissue. Structure of the AZT-curdlan sulfate was confirmed by ${ }^{1} \mathrm{H}$ and ${ }^{13} \mathrm{C}$ NMR spectroscopy. The anti-HIV activity of the AZT-curdlan sulfate complex were estimated in vitro. Investigations on the release of AZT in the presence of various enzymes (i.e., plasma and lipase) and anti-HIV activity of the released AZT are in progress. The distribution of AZT in lymphatic tissue after administration of the AZT-curdlan sulfate to animals remains to be also studied. The major objective of this study was to synthesize a new AIDS drug delivery system.

\section{EXPERIMENTAL}

\section{Materials and General Methods}

Commercial AZT was used as purchased. 4-Dimethylaminopyridine (DMAP), $N, N$-dicyclohexylcarbodiimide (DCC), sulfur trioxide-pyridine complex, and succinic anhydride (Tokyo Kaisei Kogyo Co., Ltd.) were used without further purification. Dimethyl sulfoxide (DMSO) and pyridine was distilled before use. Low molecular weight curdlan $\left(\bar{M}_{n}=1.37 \times 10^{4}\right)$ was prepared by the hydrolysis of commercial curdlan $\left(\bar{M}_{n}=8.9 \times 10^{4}\right)$ in the presence of $\mathrm{H}_{2} \mathrm{SO}_{4}$ as catalyst. ${ }^{22}{ }^{13} \mathrm{C}$ and ${ }^{1} \mathrm{H}$ NMR spectra were recorded with a JEOL LA400 spectrometer working at $100 \mathrm{MHz}$ and $400 \mathrm{MHz}$, respectively. Samples were measured on $\mathrm{D}_{2} \mathrm{O}$ or DMSO- $d_{6}$ solutions at $37^{\circ} \mathrm{C}$ and $25^{\circ} \mathrm{C}$ using sodium 4,4-dimethyl-4-sila-1-pentanesulfonate (DSS) as an internal standard. Molecular weights of AZT-curdlan sulfates were measured by aqueous-phase gel permeation chromatography (columns: TS-gel G2000SW, G3000SW, and G4000SW; 
$7.6 \mathrm{~mm} \times 600 \mathrm{~mm} \times 3$; eluent: phosphate buffer solution $(\mathrm{pH}=7.02))$ using standard pullulans as references. AZT content in the AZT-curdlan sulfate was determined by a UV spectrometer by using mixtures of $5^{\prime}$-Suc-AZT and curdlan sulfate as references. Samples were measured in $0.1 \mathrm{mg} \mathrm{ml}^{-1}$ aqueous solutions at $25^{\circ} \mathrm{C}$.

\section{Synthesis of $5^{\prime}-S u c-A Z T$}

Succinic anhydride $(0.10 \mathrm{~g})$ was added to a stirred solution of AZT $(0.15 \mathrm{~g})$ and DMAP $(0.10 \mathrm{~g})$ in pyridine $(2 \mathrm{ml})$ at $0^{\circ} \mathrm{C}$. The mixture was kept at $0^{\circ} \mathrm{C}$. The progress of the reaction was monitored by thin layer chromatography (TLC). After the reaction was completed, pyridine was evaporated under a reduced pressure. The residue was purified by column chromatography over silica gel using mixtures of methylene chloride and methanol $(7: 3-3: 1)$ as an eluent. A product of $3^{\prime}$-azido-3'-deoxy$5^{\prime}-O$-succinyl-thymidine $\left(5^{\prime}\right.$-Suc-AZT) was obtained in $73 \%$ yield.

\section{Synthesis of AZT-Curdlan}

To a curdlan $(0.1 \mathrm{~g})$ solution in DMSO $(3 \mathrm{ml})$ were added $5^{\prime}$-Suc-AZT $(0.14 \mathrm{~g})$ and DMAP $(0.10 \mathrm{~g})$. DCC $(0.20 \mathrm{~g})$ was added gradually to the above solution for $30 \mathrm{~min}$. Then, the mixture was stirred overnight at room temperature. Acetone was poured until precipitates appeared after the reaction was completed. The precipitates were collected by centrifugation, and washed 2 times with acetone $(30 \mathrm{ml})$ and $\mathrm{H}_{2} \mathrm{O}(30 \mathrm{ml})$, respectively. A white powdery AZT-bound curdlan (AZT-curdlan) $(0.12 \mathrm{~g})$ was obtained by freeze-drying from water.

\section{Synthesis of AZT-Curdlan Sulfate}

$\mathrm{SO}_{3}$-pyridine complex $(0.40 \mathrm{~g})$ was added to a AZTcurdlan $(0.10 \mathrm{~g})$ solution in DMSO $(5 \mathrm{ml})$. The mixture was stirred at room temperature for $75 \mathrm{~min}$. Then, it was neutralized by a saturated $\mathrm{NaHCO}_{3}$ solution and dialyzed against deionized water overnight. The dialyzate was concentrated under a reduced pressure, and freezedried from water to give sulfated curdlan-AZT (AZT- curdlan sulfate) $(0.16 \mathrm{~g})$.

\section{Assay of Anti-HIV Activity}

Anti-HIV activities of the AZT-curdlan sulfates were determined by their ability to protect cytopathic effects (CPE) induced by HIV-1 by use of the MTT method. ${ }^{23}$ In the microplate test ( 96 wells), MT-4 cells were placed in each well at the rate of $2.5 \times 10^{4}$ cells/well. The above cell culture was then infected by the addition of HIV$\mathrm{I}_{\mathrm{HTLV}-\text { IIIB }}$ at the multiplicity of 0.01 in the presence of various concentrations of the test compound. Mockinfected MT-4 cell was carried out in parallel to determine the cytotoxicity of the test compound. HIV-1- and mock-infected MT-4 cells were incubated for 5 days at $37^{\circ} \mathrm{C}$ in a $\mathrm{CO}_{2}$ incubator. Then, the cell suspension was collected and mixed with 3-(4,5-dimethylthiazol-2-yl)2,5-diphenyltetrazolium (MTT). The viability of both HIV-1- and mock-infected cells was measured spectrophotometrically via the reduction of MTT. A $50 \%$ effective concentration $\mathrm{EC}_{50}$ was defined as a concentration of test compound which protects $50 \%$ cells from the virus infection. A $50 \%$ cytotoxic concentration $\left(\mathrm{CC}_{50}\right)$ was determined by a $50 \%$ cytotoxic concentration of the test compound in the MT-4 cell culture.

\section{Assay of Anticoagulant Activity}

Anticoagulant activity was evaluated by a modified United States Pharmacopoeia method using bovine plasma. ${ }^{24}$ Dextran sulfate with an anticoagulant activity of 21.0 unit $\mathrm{mg}^{-1}$ was used as a reference.

\section{RESULTS AND DISCUSSION}

\section{Synthesis and Structure Analysis}

In order to synthesize a prodrug releasing AZT in living organs, desirably in lymphoid tissue, AZT was combined through a biodegradable linkage to curdlan sulfate having a property to be concentrated in lymph node. An AZT-bound curdlan sulfate was prepared by a synthetic route as illustrated in Scheme 1. AZT was

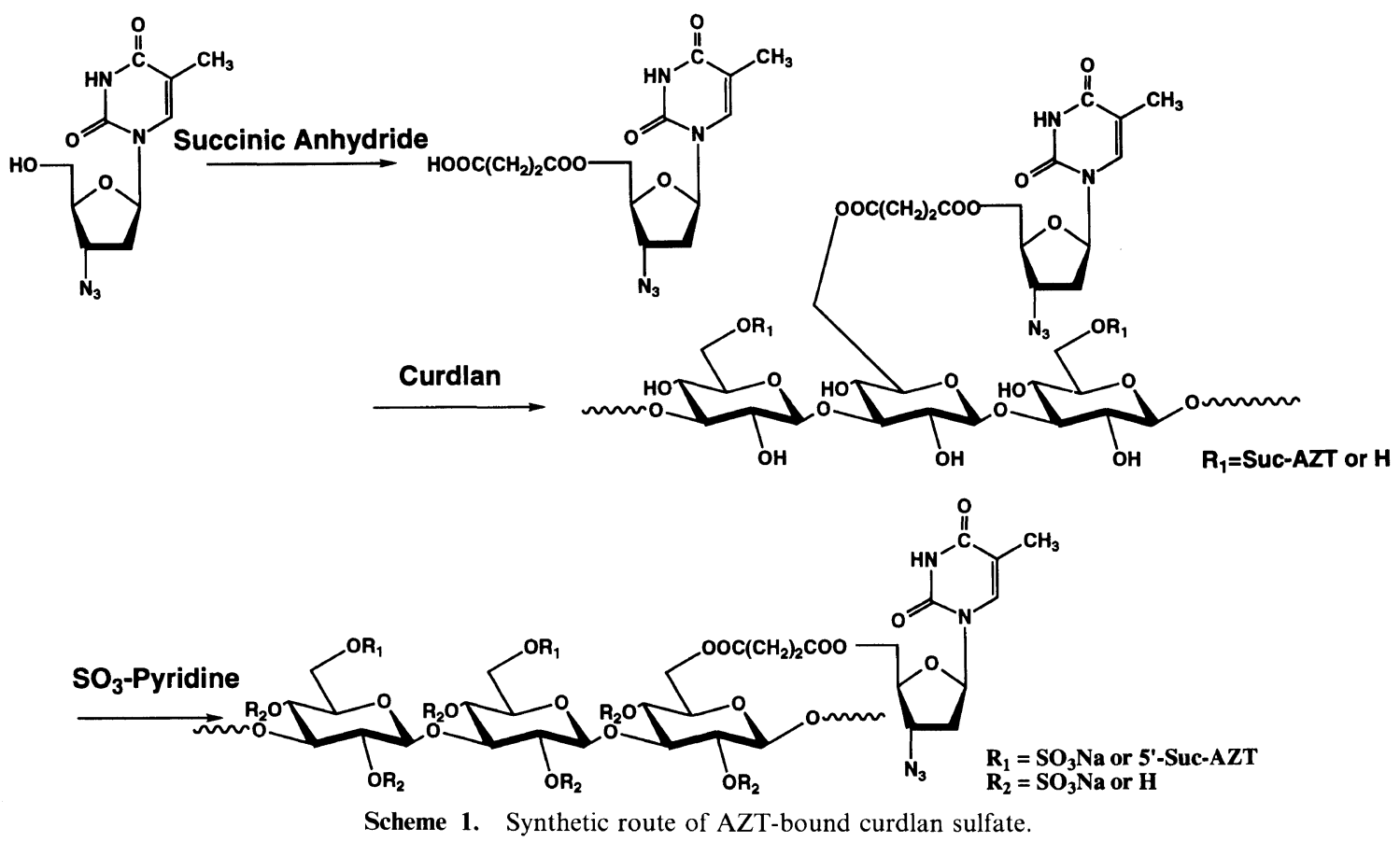




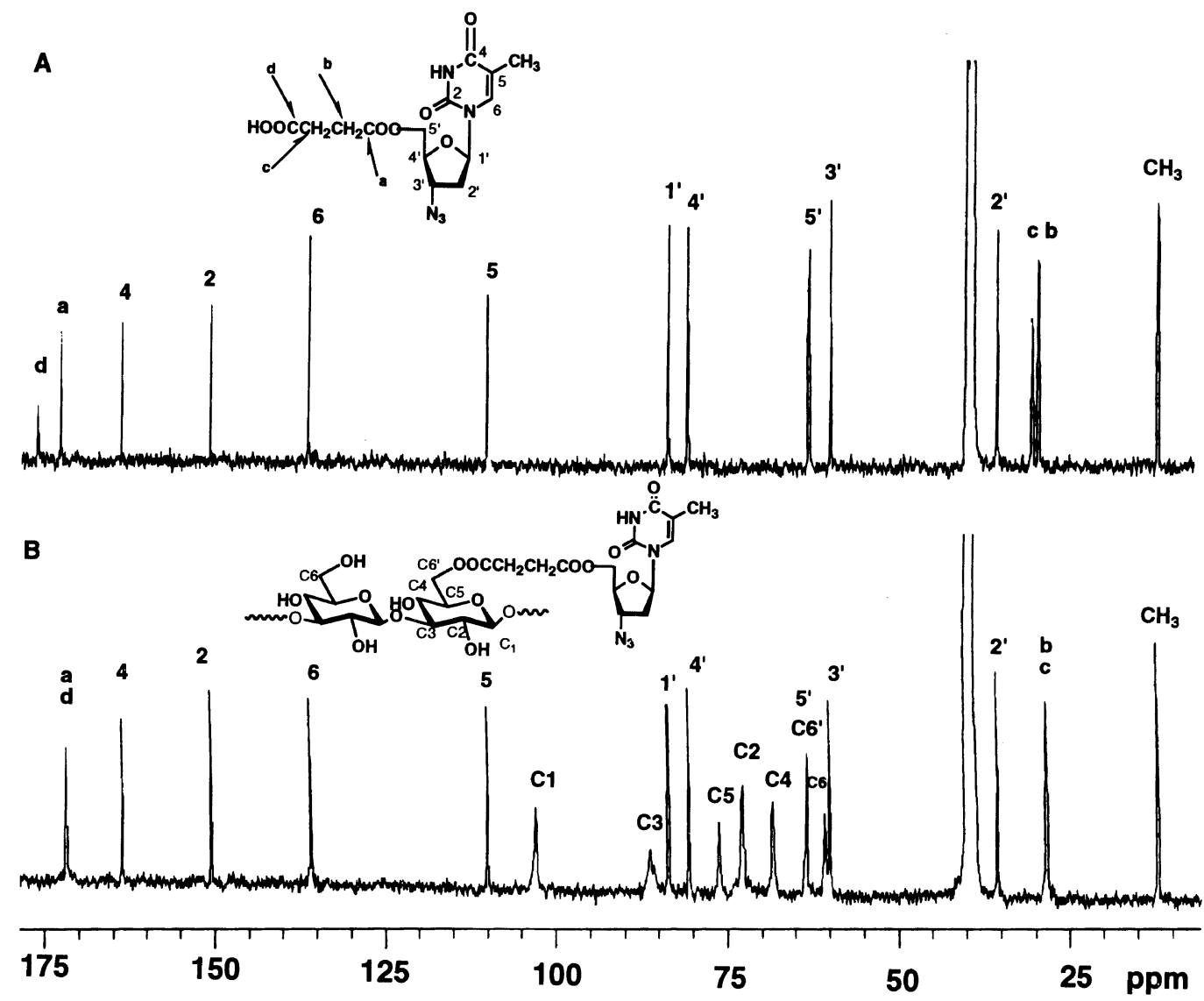

Figure 1. $100-\mathrm{MHz}{ }^{13} \mathrm{C}$ NMR spectra of (A) $5^{\prime}$-Suc-AZT and (B) AZT-curdlan $\left(d_{6}\right.$-DMSO as a solvent at $\left.25^{\circ} \mathrm{C}\right)$.

Table I. Reaction of curdlan with $5^{\prime}-$ Suc-AZT ${ }^{\mathrm{a}}$

\begin{tabular}{|c|c|c|c|c|c|c|c|c|c|c|c|}
\hline \multirow{2}{*}{ No. } & \multicolumn{2}{|c|}{ Curdlan } & \multicolumn{2}{|c|}{$5^{\prime}-$ Suc-AZT $^{\mathrm{b}}$} & \multirow{2}{*}{$\frac{\mathrm{DMAP}^{\mathrm{DCC}} \mathrm{C}^{\mathrm{c}}}{\mathrm{g} / \mathrm{g}}$} & \multirow{2}{*}{$\frac{\text { Time }}{\mathrm{h}}$} & \multirow{2}{*}{$\frac{\text { Yield }}{\mathrm{g}}$} & \multirow{2}{*}{$\begin{array}{c}\mathrm{DS}_{\mathrm{AZT}}^{\mathrm{d}} \\
\text { (AZT-bound) }\end{array}$} & \multicolumn{3}{|c|}{ Elemental Analysis $/ \%$} \\
\hline & $\mathrm{g}$ & mmol & $\mathrm{g}$ & equiv $^{e}$ & & & & & $\mathrm{C}$ & $\mathrm{H}$ & $\mathrm{N}$ \\
\hline 1 & 0.10 & 0.62 & 0.05 & 0.22 & $0.10 / 0.20$ & 48 & 0.11 & 0.15 & 42.0 & 5.6 & 5.4 \\
\hline 2 & 0.15 & 0.93 & 0.10 & 0.29 & $0.10 / 0.30$ & 24 & 0.15 & 0.16 & - & ${ }_{\mathrm{f}}$ & f \\
\hline 3 & 0.13 & 0.83 & 0.18 & 0.59 & $0.10 / 0.20$ & 48 & 0.15 & 0.18 & 42.0 & 6.0 & 5.6 \\
\hline 4 & 0.10 & 0.62 & 0.14 & 0.61 & $0.10 / 0.30$ & 48 & 0.12 & 0.20 & 41.6 & 5.7 & 6.3 \\
\hline $5^{\mathrm{g}}$ & 0.10 & 0.62 & 0.10 & 0.43 & $0.10 / 0.15$ & 24 & 0.10 & 0.29 & 43.7 & 5.2 & 9.7 \\
\hline $6^{\mathrm{g}}$ & 0.10 & 0.62 & 0.13 & 0.59 & $0.10 / 0.20$ & 24 & 0.13 & 0.50 & 46.1 & 5.1 & 12.2 \\
\hline
\end{tabular}

${ }^{\mathrm{a}}$ Reacted in DMSO at room temperature. ${ }^{\mathrm{b}} 5^{\prime}$-Succinyl-AZT. ${ }^{\mathrm{c}} 4$-Dimethylaminopyridine and $N, N$-dicyclohexylcarbodiimide. ${ }^{\mathrm{d}}$ Degree of AZT substitution to a glucose unit of curdlan. ${ }^{\mathrm{e}}$ Equiv to a glucose unit of curdlan. ${ }^{\mathrm{f}}$ Not measured. ${ }^{\mathrm{g}}$ Reaction was repeacted twice.

reacted with succinic anhydride in the presence of DMAP as a catalyst to give a $5^{\prime}$-Suc-AZT. The yield of $5^{\prime}$-SucAZT increased with increasing equiv of succinic anhydride. However, the addition of a large excess of succinic anhydride did not provide high yield. When the separation of 5'-Suc-AZT was carried out by column chromatography by use of methylenechloride and methanol mixture as an eluent, remaining succinic anhydride reacted with methanol to afford a difficultly separable byproduct. Thus, the maximum yield was obtained in $73 \%$, when AZT was reacted with 1.8 equivs of succinic anhydride.

Structure of the $5^{\prime}$-Suc-AZT was identified by ${ }^{13} \mathrm{C}$ NMR spectroscopy, as shown in Figure 1. Assignment of peaks was carried out by reference to the spectra of AZT and succinic acid. Two novel pairs of peaks around $175 \mathrm{ppm}$ and $30 \mathrm{ppm}$ were assigned to absorptions of the succinyl acid moiety.
AZT was introduced into curdlan by esterification of 5 -Suc-AZT with curdlan in the presence of DMAP and DCC as catalysts. The results are summarized in Table I. The degree of AZT substitution increased with increasing equiv of 5'-Suc-AZT. Although an increase in reaction time did not provide high degree of AZT substitution, the repeated esterification was much effective for increasing AZT substitution to reach $50 \%$. This phenomenon was consistent with the condensation of curdlan with orthoacetate. ${ }^{25}$

Structure analysis of the AZT-curdlan was performed by ${ }^{13} \mathrm{C}$ NMR spectroscopy, as also shown in Figure 1. Absorptions $\mathrm{d}$ and $\mathrm{c}$ due to carbonyl carbon and an adjacent methylene of the succinyl ester moiety, respectively, appeared at $172 \mathrm{ppm}$ and $28 \mathrm{ppm}$, which upfield shifted after the reaction with curdlan. Furthermore, absorptions due to $\mathrm{C} 1-\mathrm{C} 6$ carbons of curdlan are clearly seen in the spectrum. A part of the C6 absorption 


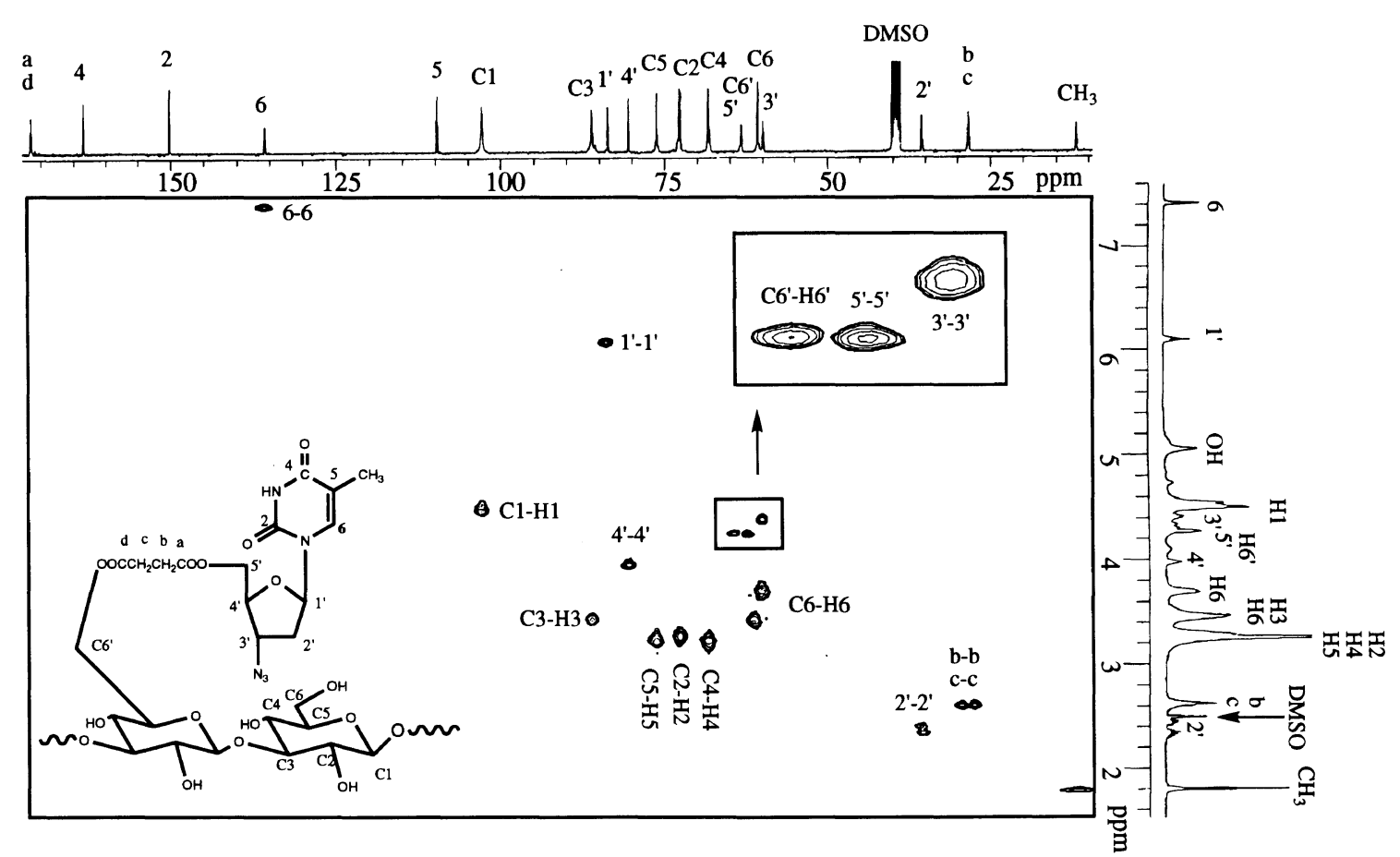

Figure 2. 2D ${ }^{13} \mathrm{C}^{-1} \mathrm{H}$ COSY-FG NMR spectra of AZT-curdlan $\left(d_{6}-\mathrm{DMSO}\right.$ as a solvent at $\left.50^{\circ} \mathrm{C}\right)$.

Table II. Sulfation of AZT-curdlan with sulfur trioxide pyridine complex ${ }^{\mathrm{a}}$

\begin{tabular}{|c|c|c|c|c|c|c|c|c|c|c|c|c|c|}
\hline \multirow{2}{*}{ No. } & \multirow{2}{*}{$\frac{\text { AZT-Curdlan }}{\mathrm{g}}$} & \multicolumn{2}{|c|}{$\mathrm{SO}_{3}-\mathrm{Py}^{\mathrm{b}}$} & \multirow{2}{*}{$\frac{\text { Time }}{\min }$} & \multirow{2}{*}{$\frac{\text { Yield }}{\mathrm{g}}$} & \multirow{2}{*}{$\begin{array}{l}\bar{M}_{n}{ }^{\mathrm{c}} \\
\times 10^{4}\end{array}$} & \multicolumn{4}{|c|}{ Elemental analysis/(\%) } & \multirow{2}{*}{$\mathrm{DSul}^{\mathrm{d}}$} & \multicolumn{2}{|c|}{ AZT-Bound } \\
\hline & & $\mathrm{g}$ & equiv & & & & $\mathrm{C}$ & $\mathrm{H}$ & $\mathrm{N}$ & $\mathrm{S}$ & & $w t \%^{e}$ & $\mathrm{DS}_{\mathrm{AZT}}^{\mathrm{f}}$ \\
\hline 1 & 0.10 & 0.40 & 4.85 & 75 & 0.16 & 1.38 & 24.6 & 3.5 & 3.7 & 12.0 & 1.31 & 11.5 & 0.15 \\
\hline 2 & 0.10 & 0.35 & 4.17 & 65 & 0.13 & 1.44 & 23.9 & 3.5 & 3.5 & 12.5 & 1.45 & 11.7 & 0.16 \\
\hline 3 & 0.10 & 0.35 & 4.35 & 75 & 0.16 & 1.37 & 22.8 & 4.2 & 3.0 & 13.1 & 1.50 & 12.9 & 0.18 \\
\hline 4 & 0.10 & 0.35 & 4.40 & 75 & 0.14 & 1.27 & 23.8 & 4.0 & 3.4 & 11.9 & 1.42 & 14.2 & 0.20 \\
\hline 5 & 0.10 & 0.35 & 4.82 & 70 & 0.13 & 一 $^{\mathrm{g}}$ & 26.4 & 3.6 & 5.6 & 11.1 & 1.43 & 18.6 & 0.29 \\
\hline 6 & 0.10 & 0.40 & 6.68 & 90 & 0.08 & $\ldots g$ & 31.8 & 3.8 & 8.5 & 8.8 & 1.31 & 28.2 & 0.50 \\
\hline
\end{tabular}

${ }^{a}$ Sulfated in DMSO at room temperature. ${ }^{\mathrm{b}}$ Sulfur trioxide pyridine complex. ${ }^{\mathrm{c}}$ Determined by GPC. ${ }^{\mathrm{d}}$ Degree of substitution of sulfate group based on a glucose unit of curdlan. ${ }^{\mathrm{e}}$ Measured by UV spectroscopy. ${ }^{\mathrm{f}}$ Degree of AZT substitution based on a glucose unit of curdlan. ${ }^{\mathrm{g}}$ Not measured.

of curdlan shifted from $61 \mathrm{ppm}$ to $64 \mathrm{ppm}$ and overlapped with the $5^{\prime}$ carbon of AZT moiety, indicating that the 6-hydroxyl group of curdlan was esterified. The absorption at $64 \mathrm{ppm}$ consisted of the overlapping of the two peaks due to $\mathrm{C}^{\prime}$ of curdlan and $5^{\prime}$ carbon of AZT moiety. This assignment was carried out by ${ }^{1} \mathrm{H}-{ }^{13} \mathrm{C}$ COSY-FG 2D-NMR, as exhibited in Figure 2. Since there was no change in the $\mathrm{C} 2$ and $\mathrm{C} 4$ carbon absorptions of curdlan after the reaction, it is clear that AZT was introduced exclusively into the C6 position of curdlan.

The AZT-curdlan was sulfated with $\mathrm{SO}_{3}$-pyridine complex to give AZT-curdlan sulfate. The results are summarized in Table II. The degree of sulfation estimated by elemental analysis in combination with UV spectroscopy was in the range of 1.3 to 1.5 . In order to obtain AZT-curdlan sulfates with high degrees of AZT substitution $\left(\mathrm{DS}_{\mathrm{AZT}}\right)$ and sulfation (DSul), it was necessary to increase both reaction time and equiv of $\mathrm{SO}_{3}$ pyridine (No. 6).

${ }^{1} \mathrm{H}$ NMR spectrum of an AZT-curdlan sulfate is shown in Figure 3. Assignment of the peaks was carried out by reference to the previous work. ${ }^{26}$ The comparison of intensity of methylene group $(2.8 \mathrm{ppm}, 4 \mathrm{H})$ of the succinyl moiety with that of methyl group $(1.8 \mathrm{ppm}, 3 \mathrm{H})$ of AZT moiety revealed that the linkage between AZT and curdlan was not broken during the sulfation. Therefore, the degree of AZT substitution to a glucose unit of curdlan did not change by the sulfation.

\section{Anti-HIV Activity and Anticoagulant Activity}

An anti-HIV activity of the AZT-curdlan sulfate was assayed by MTT method in vitro. ${ }^{23}$ HIV-1- and mockinfected MT-4 cells were incubated in the presence of various concentrations of AZT-curdlan sulfate for 5 days at $37^{\circ} \mathrm{C}$ in a $\mathrm{CO}_{2}$ incubator. The cell viability was determined by reduction of MTT dye by living cells. Table III summarizes the results of anti-HIV activities of AZT-curdlan sulfates. AZT-curdlan sulfates exhibited anti-HIV activities in the $\mathrm{EC}_{50}$ range of 0.17 to 0.58 $\mu \mathrm{g} \mathrm{ml}^{-1}$ corresponding to that of a highly active curdlan sulfate $\left(\mathrm{EC}_{50}=0.51 \mu \mathrm{g} \mathrm{ml}^{-1}\right)$, and possessed low cytotoxicities of $\mathrm{CC}_{50}$ more than $1000 \mu \mathrm{g} \mathrm{ml}^{-1}$. The antiHIV activity and low cytotoxicity indicate that the ester bond of AZT-curdlan sulfate was stable under a moderate $\mathrm{pH}$ condition in vitro, and AZT did not release from curdlan sulfate carrier, because a free AZT must 


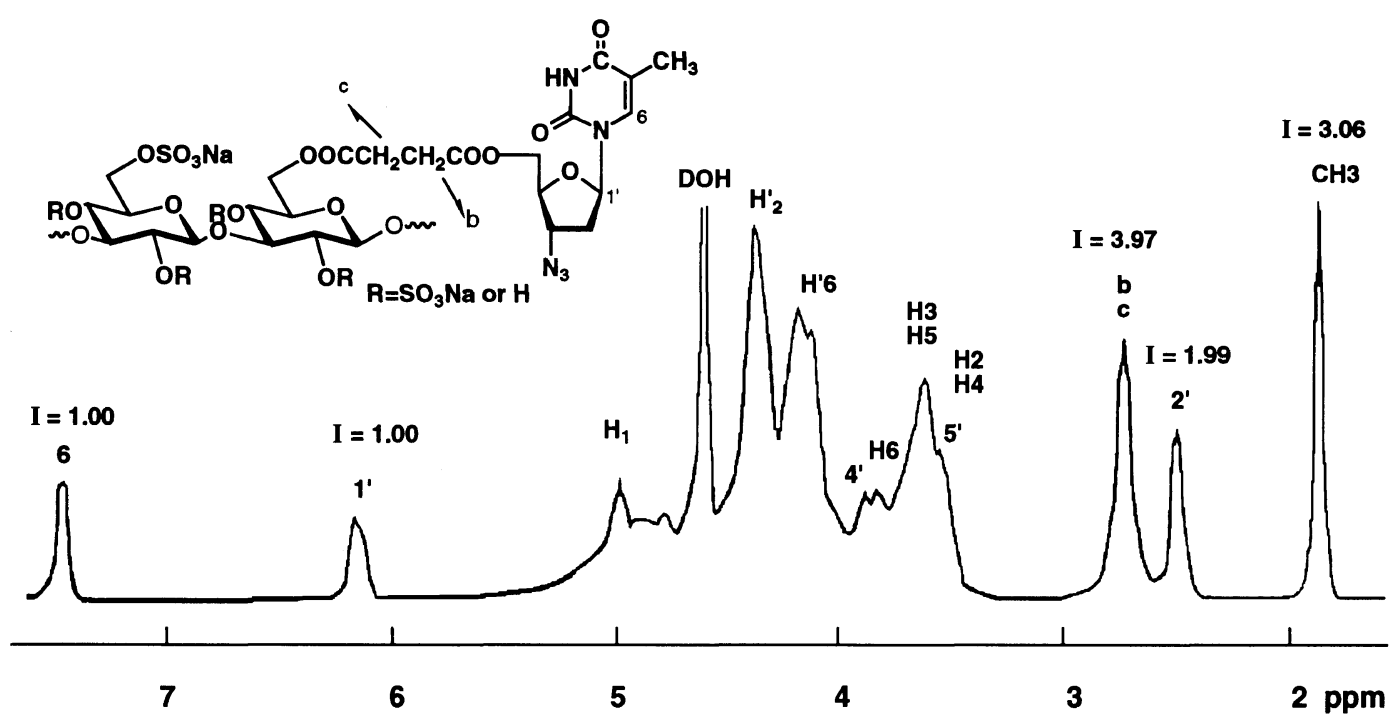

Figure 3. $400-\mathrm{MHz}{ }^{1} \mathrm{H}$ NMR spectrum of an AZT-curdlan sulfate $\left(\mathrm{D}_{2} \mathrm{O}\right.$ as a solvent at $\left.37^{\circ} \mathrm{C}\right)$.

Table III. The anti-HIV and anticoagulant activities of AZT-curdlan sulfates

\begin{tabular}{|c|c|c|c|c|c|c|c|c|c|c|c|c|}
\hline \multirow{3}{*}{ No. } & \multirow{2}{*}{\multicolumn{2}{|c|}{ AZT-Bound }} & \multirow{3}{*}{$\begin{array}{l}\bar{M}_{n} \\
\times 10^{4}\end{array}$} & \multirow{3}{*}{$\begin{array}{c}\begin{array}{c}\mathrm{S}^{\mathrm{a}} \\
\text { (content) }\end{array} \\
\frac{\%}{\%}\end{array}$} & \multirow{3}{*}{$\mathrm{DSul}^{\mathrm{b}}$} & \multicolumn{2}{|c|}{1 Day } & \multicolumn{2}{|c|}{21 Days } & \multicolumn{2}{|c|}{35 Days } & \multirow{3}{*}{$\begin{array}{c}A A^{\mathrm{g}} \\
\text { unit } \mathrm{mg}^{-}\end{array}$} \\
\hline & & & & & & $\mathrm{EC}_{50}{ }^{\mathrm{c}}$ & $\mathrm{CC}_{50}^{\mathrm{d}}$ & $\mathrm{EC}_{50} \mathrm{e}^{\mathrm{e}}$ & $\mathrm{CC}_{50} \mathrm{e}^{\mathrm{e}}$ & $\mathrm{EC}_{50}{ }^{\mathrm{f}}$ & $\mathrm{CC}_{50}{ }^{\mathrm{f}}$ & \\
\hline & $\mathrm{wt} \%$ & $\mathrm{DS}_{\mathrm{AZT}}^{\mathrm{h}}$ & & & & $\mu \mathrm{g} \mathrm{ml}^{-1}$ & $\mu \mathrm{g} \mathrm{ml}^{-1}$ & $\mu \mathrm{g} \mathrm{ml}^{-1}$ & $\mu \mathrm{g} \mathrm{ml}^{-1}$ & $\mu \mathrm{g} \mathrm{ml}^{-1}$ & $\mu \mathrm{g} \mathrm{ml}^{-1}$ & \\
\hline 1 & 0 & 0 & 1.25 & 14.0 & 1.52 & 0.61 & $>1000$ & 0.61 & $>1000$ & 0.61 & $>1000$ & 19 \\
\hline 2 & 11.5 & 0.15 & 1.38 & 12.0 & 1.31 & 0.37 & $>1000$ & 0.09 & 570 & 0.03 & 410 & 22 \\
\hline 3 & 11.7 & 0.16 & 1.44 & 12.5 & 1.45 & 0.17 & $>1000$ & 0.16 & 780 & $\ldots$ & ${ }^{i}$ & 18 \\
\hline 4 & 12.9 & 0.18 & 1.37 & 13.0 & 1.50 & 0.58 & $>1000$ & 0.14 & 650 & 0.07 & 540 & ${ }_{-i}^{i}$ \\
\hline 5 & 14.2 & 0.20 & 1.27 & 11.9 & 1.42 & 0.17 & $>1000$ & 0.07 & 780 & 0.04 & 640 & $\ldots$ \\
\hline 6 & 18.6 & 0.29 & $\mathrm{i}_{\mathrm{i}}$ & 11.1 & 1.43 & 0.50 & $>1000$ & 0.04 & 610 & 0.04 & 630 & 16 \\
\hline 7 & 28.2 & 0.50 & $-^{\mathrm{i}}$ & 8.8 & 1.31 & ${ }_{i}$ & $-i$ & 0.03 & 670 & 0.03 & 680 & 16 \\
\hline $\mathrm{CS}^{\mathrm{j}}$ & & & & 14.1 & & 0.51 & $>1000$ & 0.54 & $>1000$ & & & \\
\hline AZT $(\mathrm{mM})$ & & & & & & 0.002 & 7.8 & 0.002 & 8.6 & 0.002 & 10.2 & \\
\hline
\end{tabular}

${ }^{a}$ Determined by elemental analysis. ${ }^{\mathrm{b}}$ Degree of substitution of sulfate group to a glucose unit. ${ }^{\mathrm{c}}$ Anti-HIV activity: Drug concentration effective for $50 \%$ inhibition of virus infection in 5-day HIV-infected MT-4 cell culture. ${ }^{d}$ Cytotoxic effect: Drug concentration $50 \%$ cytotoxicity in 5-day MT-4 cell culture. ${ }^{e}$ Anti-HIV activity and cytotoxicity assayed when the compound solution was kept in a refrigerator for 21 days. ${ }^{f}$ Anti-HIV activity and cytotoxicity assayed when 35 days. ${ }^{\mathrm{g}}$ Anticoagulant activity: Commercial dextran sulfate having $21 \mathrm{unit}^{\mathrm{mg}}{ }^{-1}$ as reference. ${ }^{\mathrm{h}}$ Degree of AZT substitution to a glucose unit of curdlan. ${ }^{\mathrm{i}}$ Not measured. ${ }^{\mathrm{j}}$ Curdlan sulfate having weight average molecular weight of $7.9 \times 10^{4}$ as reference.

show higher cytotoxicity as mentioned below. It was reported that an AZT derivative having an ester linkage was stable under neutral $\mathrm{pH}$ range, whereas the ester linkage was severed enzymatically to release AZT. ${ }^{27}$ Therefore, the activity due to free AZT must not be added to the activity detected by the MTT in vitro, the anti-HIV activity of the AZT-curdlan sulfate may originate from that of curdlan sulfate moiety.

It was also found that AZT was released gradually from the AZT-curdlan sulfate when the AZT-curdlan sulfate solution in a $90 \%$ buffer at $\mathrm{pH} 7.4$ and $10 \%$ dimethyl sulfoxide mixture was kept in a refrigerator for a few weeks. The released AZT exhibited its anti-HIV activity. Therefore, as shown in Figure 4, the anti-HIV activity of the AZT-curdlan sulfate increased with increasing storage time, because the activity due to the released AZT was added to that due to the curdlan sulfate. In addition, an increase in cytotoxicity attributable to AZT was observed, as also shown in Figure 4. The phenomena were not observed when AZT-curd- lan sulfate was kept in dry powder for a few months, indicating that the AZT-curdlan sulfate is stable in dry conditions, but not in the solution. Furthermore, antiHIV activities $\left(\mathrm{EC}_{50}=0.03-0.16 \mu \mathrm{g} \mathrm{ml}^{-1}\right)$ and cytotoxicities $\left(\mathrm{CC}_{50}=400-780 \mu \mathrm{g} \mathrm{ml}^{-1}\right)$ of AZT-curdlan sulfates, which were kept in the solution, were much lower than those $\left(\mathrm{EC}_{50}=0.0003 \mu \mathrm{g} \mathrm{ml}^{-1}, \mathrm{CC}_{50}=4.2\right.$ $\mu \mathrm{g} \mathrm{ml}^{-1}$ ) of a mixture of AZT $(28.2 \%)$ and curdlan sulfate $(71.8 \%)$, suggesting that the release of AZT was very slow even in the solution.

Since an enzymatic release of AZT from azidothymidyl aliphatic ester has been reported, ${ }^{27}$ the present AZT-curdlan sulfate bound by an ester linkage must release $\mathrm{AZT}$ if it is used in living organs having ester bond-severing enzymes existing abundantly. Such an experiment will be done in future.

Anticoagulant activities of AZT-curdlan sulfates are also shown in Table III. The AZT-curdlan sulfates exhibited low to moderate anticoagulant activities ranging from 16 to 22 unit $\mathrm{mg}^{-1}$, being almost comparable to 

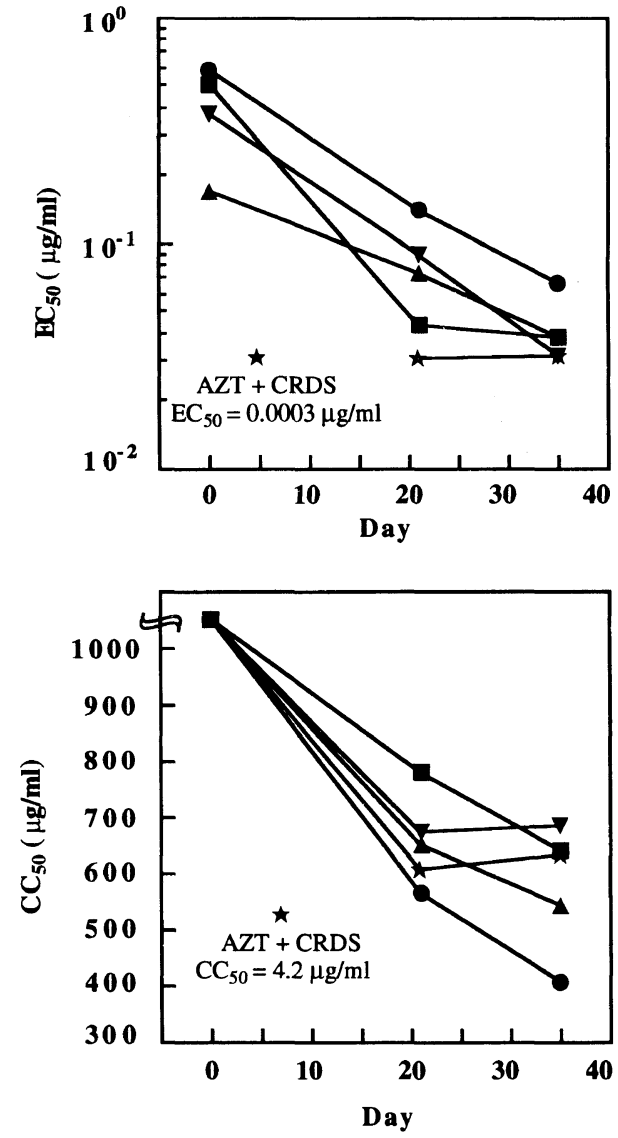

Figure 4. Dependence of both the anti-HIV activity and the cytotoxicity of AZT-curdlan sulfates on storage time of the AZT-curdlan sulfate solutions $\left(\boldsymbol{\nabla}, \mathrm{DS}_{\mathrm{AZT}}=0.15 ; \boldsymbol{\bullet}, \mathrm{DS}_{\mathrm{AZT}}=0.18 ; \boldsymbol{\Delta}, \mathrm{DS}_{\mathrm{AZT}}=0.20\right.$; $\boldsymbol{\square}, \mathrm{DS}_{\mathrm{AZT}}=0.29 ; \star, \mathrm{DS}_{\mathrm{AZT}}=0.50$ ).

that of an AZT-free curdlan sulfate (No. 1). It was revealed that the substitution of curdlan sulfate by AZT did not increase the anticoagulant activity which is regarded as a serious side effect for an anti-HIV agent.

\section{REFERENCES}

1. G. Pantaleo, C. Graziosi, J. F. Demarest, L. Butin, M. Montroni, C. H. Fox, J. M. Orenstein, D. P. Kotler, and A. S. Fauci, Nature, 362, 355 (1993).

2. J. Embretson, M. Zupancic, J. L. Ribas, A. Burke, P. Racz, K. Tenner-Racz, and A. S. Haase, Nature, 362, 359 (1993).

3. M. Seligmann, D. A. Warrell, J. P. Aboulker, C. Carbon, J. H. Darbyshire, J. Dormont, E. Eschwege, D. J. Girling, D. R. James, J. P. Levy, T. E. A. Peto, D. Schwarz, A. B. Stone, I. V. D. Weller, R. Withnall, K. Gelmon, E. Lafon, A. M. Swart, V. R. Aber, A. G. Babiker, S. Lhoro, A. J. Nunn, and M. Vray, Lancet, 343, 871 (1994).
4. K. K. Manouilov, I. I. Fedorov, F. D. Boudinot, C. A. White, L. P. Kotra, R. F. Schinazi, C. D. II. Hong, and C. K. Chu, Antiviral Chem. Chemother., 6, 230 (1995).

5. K. K. Manouilov, C. A. White, F. D. Boudinot, I. I. Fedorov, and C. K. Chu, Drug Metabolism and Disposition, 23, 655 (1995).

6. B. A. Larder, G. Darby, and D. D. Richman, Science, 243, 1731 (1989).

7. M. Baba, D. Schols, R. Pauwels, H. Nakashima, and E. De-Clercq, J. Acquired Immunodeficiency Syndromes, 3, 493 (1990).

8. M. Holodniy, S. Kim, D. Katzenstein, M. Konrad, E. Groves and T. C. Merigan, J. Clin. Microbiol., 29, 676 (1991).

9. T. Moriya, H. Kurita, K. Matsumoto, T. Otake, H. Mori, M. Morimoto, N. Ueba, and N. Kunita, J. Med. Chem., 34, 2301 (1991).

10. E. Mbemba, V. Chams, J. C. Gluckman, D. Klatzmann, and L. Gattegno, Biochim. Biophys. Acta, 62, 1138 (1992).

11. R. Ueno and S. Kuno, Lancet, 13, 1397 (1987).

12. H. Mitsuya, D. J. Looney, S. Kuno, R. Ueno, F. W. Staal, and S. Broder, Science, 240, 646 (1988).

13. C. Flexner, P. A. Barditch-crovo, D. M. Kornhauser, H. Farzadegan, L. J. Nerhood, R. E. Chaisson, K. M. Bell, K. J. Lorentsen, C. W. Hendrix, B. G. Petty, and P. S. Lietman, Antimicrob. Agents Chemother., 35, 2544 (1991).

14. K. Hatanaka, T. Yoshida, T. Uryu, O. Yoshida, H. Nakashima, N. Yamamoto, T. Mimura, and Y. Kaneko, Jpn. J. Cancer Res., 80, 95 (1989).

15. Y. Kaneko, O. Yoshida, R. Nakagawa, T. Yoshida, M. Date, S. Ogihara, T. Shioya, Y. Matsuzawa, H. Shinkai, N. Yasuda, K. Matsuzaki, T. Uryu, and N. Yamamoto, Biochem. Pharmacol., 25, 163 (1990).

16. T. Yoshida, K. Hatanaka, T. Uryu, Y. Kaneko, E. Suzuki, H. Miyano, T. Mimura, O. Yoshida, and N. Yamamoto, Macromolecules, 23, 3717 (1990).

17. T. Uryu, N. Ikushima, K. Katsuraya, T. Shoji, N. Takahashi, T. Yoshida, K. Kanno, T. Murakami, H. Nakashima, and N. Yamamoto, Biochem. Pharmacol., 43, 2385 (1992).

18. K. Katsuraya, N. Ikushima, N. Takahashi, T. Shoji, H. Nakashima, N. Yamamoto, T. Yoshida, and T. Uryu, Carbohydr. Res., 260, 51 (1994).

19. K. Katsuraya, T. Shibuya, K. Inazawa, H. Nakashima, N. Yamamoto, and T. Uryu, Macromolecules, 28, 6697 (1995).

20. M. Gordon, M. Guralnik, Y. Kaneko, T. Mimura, M. Baker, and W. Lang, J. Med., 25, 163 (1994).

21. T. Uryu, Y. Kaneko, T. Yoshida, R. Mihara, T. Shoji, K. Katsuraya, H. Nakashima, and N. Yamamoto, in Carbohydrates and Carbohydrates Polymer, M. Yalpani, Ed., ATL Press, Mount Prospect, IL, 1993, p 101.

22. Y. Gao, A. Fukuda, K. Katsuraya, Y. Kaneko, T. Mimura, H. Nakashima, and T. Uryu, Macromolecules, 30, 3224 (1997).

23. R. Pauwels, J. Balzarini, M. Baba, R. Snoeck, D. Schols, P. Herdewijn, J. Desmyter, and E. De Clercq, J. Virol. Methods, 20, 309 (1988).

24. K. Hatanaka, T. Yoshida, S. Miyahara, T. Sato, F. Ono, T. Uryu, and H. Kuzuhara, J. Med. Chem., 30, 810 (1987).

25. T. Yoshida, Y. Yasuda, T. Uryu, H. Nakashima, N. Yamamoto, T. Mimura, and Y. Kaneko, Macromolecules, 27, 6272 (1994).

26. T. Yoshida, Y. Yasuda, T. Mimura, Y. Kaneko, H. Nakashima N. Yamamoto, and T. Uryu, Carbohydr. Res., 276, 425 (1995).

27. T. Kawaguchi, K. Ishikawa, T. Seki, and K. Juni, J. Pharm. Sci., 79, 531 (1990). 